past history so that they may impose an appropriate penalty, ${ }^{3 z}$ but this procedure greatly increases the possibility that the verdict will be influenced by factors not relevant to the question of the defendant's guilt or innocence. ${ }^{33}$

When the court imposes punishment the jury must be discouraged from acquitting defendants whose guilt is certain but whom they are unwilling to convict because they fear that the penalty will be too harsh. Permitting the jury to recommend mercy is therefore desirable, since it would tend to eliminate that fear. Yet if the rule of reasonable doubt is to be adhered to, either juries must be more strictly controlled in making recommendations of mercy, or it must be admitted that the policy of the law has changed and that in doubtful cases it is now preferable to convict defendants and allow jurors to ease their consciences in so doing by convincing themselves that the penalty will be light.

\title{
IIMITATIONS ON THE AVAILABILITY OF SPECIFIC PERFORMANCE
}

Normally the damages which are awarded for breach of contract are intended to put a plaintiff in as good a position as he would have been in had the agreement been carried out. Such expectation damages insure a rough measure of compensation for hard-to-prove or hard-to-measure elements of reliance and for the distress and insecurity which result from failure to keep promises. In addition, good guesses about future needs in our free enterprise economy are rewarded. One would therefore naturally expect that the plaintiff would be given, whenever possible, an exact equivalent of performance, rather than its approximation in damages. ${ }^{1}$ Yet specific performance remains an extraordinary remedy because of the rules defining the jurisdiction of the chancellor and those limiting the exercise of his power. The law of Illinois, as elsewhere, has been most troubled by the doctrines concerning the adequacy of legal remedy, extended performance, mutuality of remedy, and the enforcement of "negative" promises.

\section{I}

Inadequacy of the remedy at law is the basis for equitable jurisdiction to decree specific performance. ${ }^{2}$ From this premise the courts have developed a I940).

${ }^{32}$ Ill. Rev. Stat. (1947) c. $38 \$ \S 473,602$; see I Wigmore, Evidence, $\S$ Ig6(2)(b) (3d ed.,

${ }^{33}$ This difficulty has been avoided in some states by permitting the jury to hear evidence of the defendant's background and past convictions only after their verdict has been returned. I Wigmore, Evidence $\S$ Ig6(2)(a) (3d ed., r940).

${ }^{1}$ On the theory of contract damages see Sharp, Promissory Liability. I, 7 Univ. Chi. L. Rev. I, 17 (1939); Fuller and Perdue, The Reliance Interest in Contract Damages, 46 Yale L.J. 52 (1936), 46 Yale L.J. 373 (1937).

2 Maitland, Equity 30r (2d ed. I936); 2 Story, Equity Jurisprudence $\S 993$ (r4th ed. I9I8). 
highly elaborate body of doctrine. Contracts to convey land, unlike personal property contracts, will be specifically enforced as a matter of course. ${ }^{3}$ The realty is presumed to be "unique and impossible of duplication by the use of any amount of money." $"$ When the contract is to transfer both real and personal property, it will, as a matter of convenience, be enforced in its entirety. ${ }^{5}$ Possibly this rule underlies the specific enforcement of family agreements settling the disposition of a decedent parent's estate. ${ }^{6}$ However, the broad statements of the court emphasize a policy in favor of the prevention of family quarrels which would fully apply to contracts involving only personalty. ${ }^{7}$

More typically, specific performance of a contract involving personal property can be had only upon a showing that the plaintiff would be unable to purchase the same quantity of like articles with the damages awarded ${ }_{s}^{8}$ Thus, the contract will be enforced where the particular chattel has a unique or sentimental value to the buyer-a pretium affectionis. ${ }^{9}$ And despite early caution, ${ }^{10}$ specific performance will today be granted a contract for the sale of stock where the shares have no market value and cannot be easily obtained. ${ }^{11}$. In accord with land-contract precedents, ${ }^{12}$ the seller of stock, as well as the purchaser, has been allowed specific performance. ${ }^{13}$. Though such relief is usually justified in terms of "mutuality," the purchase price is certainly a better remedy than damages in cases where market value cannot be computed accurately $y_{\uparrow}$ The

${ }^{3}$ See Parker v. Garrison, 6I Ill. 250, 252 (I87r).

${ }^{4}$ Rest., Contracts $\$ 360$ comment a (I932).

${ }^{5}$ See Kuhn v. Sohns, 324 Ill. 48, 53, r54 N.E. 4 OI, 403 (r926).

${ }^{6}$ Only in Dunham v. Slaughter, 268 Ill. 625, Iog N.E. 673 (I9I 5), was the decision explicitly based on this ground. However, real estate was involved in the other cases where specific performance was decreed. Stedman v. Tate, $3_{26}$ IIl. 442, I58 N.E. $\$ 7$ (I927); Cole v. Cole, $292 \mathrm{IIl}$. I54, I26 N.E. 752 (I920); Hall v. Hall, I 25 IIll. 95, I6 N.E. 896 (I888); cf. McDole v. Kingsley, I63 Ill. 433,45 N.E. 28 I (1896).

${ }^{7}$ See Hall v. Hall, I25 Ill. 95, Ior, I6 N.E. 896, 897 (1888), where the court said, "This is an agreement of a most praiseworthy kind, - an amicable arrangement amongst brothers and sisters of difficulties between them.... It is an agreement which a court of equity will look upon favorably, and readily interpose for its specific performance. ..."

${ }^{8}$ See cases cited in $5^{2}$ A.L.R. 4 (x944).

9 Rest., Contracts $\S 36 \mathrm{r}$ (b) (1932); see G. C. Outten Grain Co. v. Grace, 239 Ill. App. 284, $292\left(x_{925}\right)$.

${ }^{10}$ In Barton v. DeWolf, 108 Ill. I95 (I883), and Pierce v. Plumb, 74 IIl. 326 (I874), specific performance was denied even though the stock was seldom found for sale.

11 Arentsen v. Sherman Towel Service Corp., 352 Ill. 327, x85 N.E. 327 (x933) (corporation was vendee); Smurr v. Kamen, 3 OI Ill. $x 79$, 133 N.E. 715 (I92I); Hills v. McMunn, 232 Ill. 488,83 N.E. 963 (1908); cf. Ames v. Witbeck, I79 Ill. 458, 53 N.E. 969 (r899), granting specific performance of the defendant corporation's contract to is;ue bonds and stock, as well as restoring to the corporation property which the other defendants had fraudulently taken.

12 Wright v. Buchanan, 287 Ill. 468, x23 N.E. 53I (I9r9); Robinson v. Appleton, I24 Ill. 276, 5 N.E. 76I (1888).

${ }^{13}$ Peck v. Beacom, 272 Ill. App. 424 (r933). 
early case of Anderson $v$. Olsen, ${ }^{14}$ denying equitable relief to the seller of a patent, would thus seem wrong. ${ }^{15}$

The probability that damages awarded could not in fact be collected is a further ground for granting specific performance. In Benefit Ass'n v. Sears, ${ }^{16}$ the defendant mutual insurance company was for this reason ordered to levy an assessment and pay to the beneficiary the sum collected. The courts have also been willing to enforce specifically a contract for the sale of a standard commodity, such as corn, against an insolvent vendor. ${ }^{17}$ Of course, specific performance should not be decreed where it would constitute a preference under bankruptcy law. ${ }^{18}$ Still different grounds for equitable jurisdiction are found in Fleming v. Peterson, ${ }^{19}$. where a contract to make quarterly payments of alimony was specifically enforced. Neither multiple actions to recover the installments as they came due nor recovery in one lump sum of the estimated present value of the annuity were thought adequate remedies. Specific performance has also been granted contracts to make weekly payments of union sick-benefits. ${ }^{20}$ But a contrary result was reached when the contract was to pay commissions to an agent upon the renewal of insurance policies solicited by him. ${ }^{21}$ The most liberal Illinois decision was that in the old case of McMullen $v$. Vanzant. ${ }^{22}$ The defendant had destroyed his promissory note after gaining possession from his elderly mother-in-law by promising to return it or execute a similar one. In authorizing specific performance, the court stated only that the remedy at law might not be adequate. Though later courts have attempted other rationalizations of the decision, the reprehensible nature of the defendant's conduct seems the best explanation. ${ }^{23}$

14 I88 I1l. 502, 59 N.E. 239 ( 9900$)$.

${ }^{15}$ The court in this case considered damages to be an adequate remedy and found the socalled "affirmative doctrine of mutuality" inapplicable because the buyer of a patent was not in all cases entitled to specific performance. But cf. Whitney v. Burr, II5 IIl. 28 (1885).'

${ }^{16}$ I 4 IIll. I08, 29 N.E. 480 (I885).

${ }^{17}$ Parker v. Garrison, 6r Ill. $25^{\circ}$ ( $187 x$ ).

18 Rest., Contracts $\S 362$ (r932); see Equity-Insolvency as Grounds for Granting Specific Performance of a Contract, I8 Neb. L. Bull. 2I 8 (x939).

${ }^{19}{ }_{167}$ Ill. 465,47 N.E. 755 (I897).

${ }^{20}$ Olinski v. Milk Wagon Drivers' Union, Local 753, 320 Ill. App. $487,5 x$ N.E. 2 d 707 (1943); Jansen v. Milk Wagon Drivers' Union, Local 753, 320 Ill. App. 435, 5 I N.E. 2d 62 I (1943). Contra: Ingram v. Hammer Bros. White Lead Co., 269 Ill. App. 87 (I933), denying specific performance of an employer's contract to pay a disabled employee $\$ 8.00$ per week for life.

${ }^{21}$ Schmitt v. King, 234 Ill. App. 335 (1924).

2273 Ill. I9o ( 1874$)$.

${ }^{23}$ In Cohn v. Mitchell, II 5 Ill. I24, I3I (1885), a later court decided that fraud and an express trust were the basis of the decision in the Vanzant case. However, the appellate court in G. C. Outten Grain Co. 7 Grace, 239 Ill. App. 284, 290 (I925), found the key in the high interest rate of the note and the possibility of the witnesses dying before the note matured. An unconsidered possibility was the plaintiff's mental insecurity pending the time when an action at law could be brought. Compare Rowell v. Covenant Mutual Life Ass'n, 84 Ill. App. 304 ( 1899 ), where the court enjoined the wrongful forfeiture of a life insurance policy by the insurance company. 
This requirement that plaintiff prove inadequacy of legal remedy, while not likely to lead to shocking injustice, seems lacking in practical justification. It would appear more sensible to permit the plaintiff to determine which remedy would most benefit him. At the very least, a waste of time and effort by the courts and litigants would no longer be necessary. Allowing a buyer to replevy goods once title has passed ${ }^{24}$ underlines the arbitrariness of the present limitations on the availability of specific performance. The limitations are not found in continental law. ${ }^{25}$ In fact, the doctrine appears to be an historical accident, a result of the old conflict between law and equity in seventeenthcentury England. ${ }^{26}$ Justice Story's statement is an apt one: "The truth is, that upon the principles of natural justice Courts of Equity might proceed much further and might insist upon decreeing a specific performance of all bona fide contracts. ... There is no pretense for the complaints ... that such relief in equity would wholly subvert the remedies by actions of the case and actions of covenant; for it is against conscience that a party should have a right of election whether he would perform his covenant or only pay damages for the breach of it." 27

\section{II}

The reluctance of equity to enforce building contracts or other contracts involving extended operations was summarized in Langdell's generalization, "If a contract consists in giving (dando), equity can enforce a specific reparation for a breach of it; if it consists in doing (faciendo) it cannot." 28 The dictum that equity will not undertake specific performance "where the contract calls for a succession of acts whose performance can not be consummated by one transaction, and which requires protracted supervision"29 is familiar. The Illinois courts have uniformly refused to enforce building contracts. ${ }^{30}$ There is, however, indication that specific performance will be granted in cases where the specifications are reasonably definite and the legal remedy is very inadequate. ${ }^{31}$ Such an exception to the "general rule" is typically recognized

${ }^{24}$ Rudin v. King-Richardson Co., $3^{11}$ Ill. 513, I43 N.E. 198 (1924).

${ }^{25} 3$ Williston, Sales $\S 60$ r (rev. ed. I948).

${ }^{26}$ Indeed, personal property contracts may have been enforced without regard to adequacy of legal remedy in cases as late as I640. 5 Holdsworth, History of English Law 322 (3d ed. r924).

${ }^{27}{ }_{2}$ Story, Equity Jurisprudence $\$ 994$ (14th ed. IgI8). See also Union Pacific Ry. Co. v. Chicago Ry. Co., I63 U.S. 564, 600 (I896), where Chief Justice Fuller told of the "intolerable travesty of justice involved in permitting parties to refuse performance of their contracts at pleasure by electing to pay damages for the breach."

${ }^{28}$ Langdell, A Brief Survey of Equity Jurisdiction 47.

29 Hernreich v. Lidberg, I05 Ill. App. 495, 500 (I903).

${ }^{30}$ Klingbeil v. Becklenberg, 249 Ill. App. 39 (I928); Davis v. Rose, 200 Ill. App. 329 (I9r7); Braithwaite v. Henneberry, I24 Ill. App. 407 (I906), aff'd 222 Ill. $5 \circ, 78$ N.E. 34 (Ig06).

${ }^{31}$ See Klingbeil v. Becklenberg, 249 Ill. App. 39, 43 (xو28). 
when the defendant has undertaken to build on land in his possession so that the plaintiff cannot measure damages by employing a third party to do the work. ${ }^{32}$ During the housing shortage specific performance should be more readily available, but it remains unlikely that the Illinois courts will grant the remedy except in cases of unusual hardship.

While the courts have not found occasion to decree specific performance, the Illinois cases indicate that a more liberal rule applies when the contract involves the public interest. It is true that in Henry County v. Winnebago Drain $\mathrm{Co}^{33}$ specific performance was denied in the case of a contract to drain swamp lands conveyed by the plaintiff county to the defendant. But reconveyance of the lands to the county mitigated the harshness of that decision. In the later case of Canal Comm'rs v. Sanitary Dist. of Chicago ${ }^{34}$ Justice Cartwright said, "It is undoubtedly true that where an action at law would not afford adequate relief, equity will require performance of continuous acts. In such a case the court might run a railroad, or compel the operation of pumping works, the purchase of new pumps, the collection of taxes to pay the expenses and other things of that kind."35

Despite this indication that in cases of extended performance the duty of the court is to weigh the benefits to plaintiff and public against the difficulties of enforcement, ${ }^{36}$ the rule denying equitable relief appears to have been carried to unreasonable lengths. Thus, 'specific performance was unavailable when the contracts were to finance and support a settlement house, ${ }^{37}$ to manufacture machines, ${ }^{38}$ to elect annually corporate officials, ${ }^{39}$ and to make monthly payments into a bond redemption sinking fund. ${ }^{40}$ In all of these instances, how-

\footnotetext{
Wolverhampton Corporation v. Emmons, I K.B. $5 x_{5}$ (Igor); Jones v. Parker, I6 3 Mass. 564,40 N.E. I044 (1895); 5 Williston, Contracts $\S 1_{423}$ (rev. ed. I937); Pomeroy, Specific Performance of Contracts $\$ 23$ (3d ed. I926). In Klingbeil v. Becklenberg, 249 Ill. App. 39 (I 28 ), the defendant was owner of the premises, but there the plaintiff was in possession under a long-term lease. The additional factor of an indefinite contract was present in Braithwaite $\mathrm{v}$. Henneberry, I24 Ill. App. 407 (Ig06).

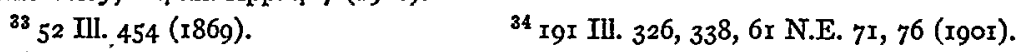

${ }^{35}$ In the particular case the court refused to enforce specifically the contract of the defendant sanitary district to pump sufficient water into the Illinois and Michigan Canal so as to maintain perpetually a navigable depth. This result was dictated largely by the court's view that the contract was unfair.

${ }^{36}$ Compare the "balance of convenience" doctrine whereby the court weighs the hardship to defendant and public against benefit to the plaintiff in determining whether or not to decree specific performance. C., B. \& Q. R. Co. v. Reno, II3 Ill. 39 (I885); C. \& A. R. Co. v. Schoeneman, 90 Ill. 258 ( 1878 ). In appraising these decisions it should be remembered that the defendant railroads could have condemned the plaintiff' contract rights in eminent domain proceedings.

37 Barker v. Hauberg, 325 Ill. 538, I56 N.E. 806 (1927).

${ }^{38}$ Almar Forming Mach. Co. v. F. \& W. Metal F. Mach. Co., 30 r Ill. App. 59r, 23 N.E. $2 d$ 229 (1939).

${ }^{39}$ Hernreich v. Lidberg, I05 Ill. App. 495 (I903).

${ }^{40}$ Langson v. Goldberg, 298 Ill. App. 229, 18 N.E. 2 d 729 (1939), aff'd 373 Ill. 297, 26 N.E. 2d III (1940) (extended performance doctrine not referred to by the Dlinois Supreme Court).
} 
ever, there were alternative grounds of decision and the supposed difficulty of enforcement may have been no more than a makeweight. The cases where specific performance was granted contracts for the periodical payment of money support this conclusion. ${ }^{41}$ Yet clearly the plaintiff must often be remitted to an inferior legal remedy under this doctrine. ${ }^{42}$ The supposed difficulties of enforcement have been exaggerated. The chancellor will not have to take personal charge of the construction of buildings or drainage of swamps. He will need no greater expert ability than a jury determining whether the contract has been broken. And the objection that too much of the court's time would be consumed disregards the savings which result from fewer actions at law. The danger of wilfully repeated breach seems remote in view of the court's contempt power. Moreover, the analogy of receivership proceedings and the successful enforcement in other jurisdictions of contracts involving very extended operations ${ }^{43}$ argue against the limitations imposed. Professor Page's suggestion that the rules are a vestige of outmoded ideas of the "dignity and leisure of a court of equity" seems well founded. ${ }^{44}$

The necessity of extended supervision by the court has also been emphasized in the decisions denying specific performance of personal service contracts. ${ }^{45}$ But here other factors aid in justifying the result. There can be real practical difficulties in insuring satisfactory performance of a contract to manage a business. ${ }^{46}$ Enforcement of many agreements would necessitate the continuance of intolerable personal associations. ${ }^{47}$ Moreover, compelling an

${ }^{41}$ Fleming v. Peterson, I67 Ill. 465, 47 N.E. 755 (I897); Olinski v. Milk Wagon Drivers' Union, Local 753, 320 Ill. App. 487, 5r N.E. $2 d 709$ (I943). Contra: Schmitt v. King, 234 Ill. App. 335 (r924).

42 See Texas Ry. Co. v. Marshall, $x_{3} 6$ U.S. 393, 405 ( 1890 ), where, in denying specific performance of the railroad's contract to establish a terminus at the city, Justice Miller said, "Though there may not be any rule by which these damages can be estimated with precision, this is not a conclusive objection against a resort to a court of law, for it is well known that in all judicial proceedings for injuries inflicted ... the relief given by way of damages is never the exact sum which compensates for the injury done, but, with all the rules which have been adopted for the measurement of damages, the relief is only approximately perfect."

${ }^{43}$ Union Pacific Ry. Co. v. Chicago Ry. Co., 163 U.S. 564 (r896) (contract by one railroad giving another a right to use its tracks, continuous running arrangements being required); P. P. \& C. I. R. Co. v. C. I. \& B. R. Co., I44 N.Y. $1_{52}, 39$ N.E. $7_{7}$ (1894) (contract to operate streetcar lines); see Specific Performance of Contracts Requiring the Court's Extended Supervision, 25 Iowa L. Rev. 766 (1940).

146 Page, Contracts $\$ 3354$ (2d ed. I922).

${ }^{45}$ See Clark v. Truitt, $x 83$ III. 239, 245, 55 N.E. 683,685 (I899); 5 Williston, Contracts $\S$ I423 A (rev. ed. 1937); Stevens, Involuntary Servitude by Injunction, 6 Corn. L. Q. 235, 239-4I (I92I).

${ }^{46}$ Clark v. Truitt, 183 Ill. 239, 55 N.E. 683 (I899) (partnership contract); cf. Kennicott v. Leavitt, 37 Ill. App. 435 (I890) (suit brought by party employed to manage theatre).

47 See Rath v. Degener, 352 Ill. I35, I38, r85 N.E. 223, 224 (r933) (contract to convey land in return for support and maintenance); Clark v. Truitt, $x 8_{3}$ Ill. $239,245,55$ N.E. 683,685 (r89g) (partnership contract); Donker \& Williams Co. v. Vance, 2 III. C.C. $x_{2}$, I $_{5}$ (IgO0) (employment contract). 
employee to fulfill his contract may be thought to create a condition approaching involuntary servitude. ${ }^{48}$ However, not all applications even of this rule have been warranted by the underlying policies. ${ }^{40}$ Wollensak v. Briggs ${ }^{50}$ is a case in point. There the court refused to enforce the defendant inventor's promise to build machinery even to the limited extent of compelling the exhibition of plans previously prepared and the disclosure of the principle of the machines already built.

\section{III}

Limitations on the availability of specific performance have been given double effect through the discredited doctrine of mutuality of remedy. Under Lord Justice Fry's statement of the rule, "[a] contract to be specifically enforced by the Court must, as a general rule, be mutual-that is to say, such that it might, at the time it was entered into, have been enforced by either of the parties against the other of them." ${ }^{11}$ In accordance with the doctrine, the Illinois courts have refused to enforce personal service ${ }^{52}$ or construction contracts $^{53}$ against either party. However, the status of the rule is today in doubt. Ill-advised references to the doctrine in the cases have given it a false appearance of strength. For example, the courts have appealed to Fry's pronouncements in determining such extraneous issues as the proper joinder of parties ${ }^{54}$ or the existence of a legally binding contract. ${ }^{55}$ Absence of mutuality of remedy is the apparent basis for refusing to enforce contracts which the plaintiff could terminate by notice or nominal payment. ${ }^{56}$ Specific enforcement of the plain-

${ }^{48}$ See Stevens, Involuntary Servitude by Injunction, 6 Corn. L. Q. 235 (I921); Donker \& Williams Co. v. Vance, 2 Ill. C.C. I2, I5 (I900).

${ }^{49}$ Limitations have been placed on this rule. Thus, the courts have enjoined breach of a union's no-strike pledge, Preble v. Architectural Union, 260 IIl. App. 435 (r93 I), and enforced contractual seniority rights in favor of laid-off workmen. Ledford v. Chicago, M., St. P. \& P. R. Co., 298 Ill. App. 298, I8 N.E. 2d 568 (1939). Compare Labor-Management Relations Act $\S \mathrm{IO}(\mathrm{c}), 6 \mathrm{r}$ Stat. $\mathrm{I}_{47}$ (I947), 29 U.S.C.A. $\$ \mathrm{I} 60$ (r947), authorizing reinstatement as a remedy for unfair labor practices.

5020 Ill. App. 50 (r886), aff'd Irg IIl. 453, I0 N.E. 23 (I887).

51 Fry, Specific Performance $\$ 460$ (6th ed. rg2r).

52 Rath v. Degener, 352 III. 135, 185 N.E. 223 (1933); Barker v. Hauberg, 325 Ill. 538, 156 N.E. 806 (1927); Reid Ice Cream Co. v. Stephens, 62 Ill. App. 334 (1895). It should be noted that the policy against forced personal association may often apply against enforcement in either direction.

${ }^{53}$ Suburban Construction Co. v. Naugle, 70 Ill. App. 384 (1897); Harley v. Sanitary District of Chicago, 54 Ill. App. 337 (I894).

${ }^{54}$ See Wurn v. Berkson, 305 Ill. 23I, 236, I37 N.E. I4I, I43 (1922).

${ }^{55}$ See Hotel BIdg. Corp. v. Dunlap Hotel Co., 350 Ill. 45I, 460, I83 N.E. 397,400 (I932); Africani Loan Ass'n v. Carroll, 267 Ill. 380,395 , 108 N.E. 322, 327 (19I5); Tryce v. Dittus, x 99 IIl. 189 , I99, 65 N.E. 220, 223 (I902); Lancaster v. Roberts, I44 Ill. 2r3, 223 (I893).

66 Ulrey v. Keith, 237 Ill. 284,86 N.E. 696 (rgo8) (covenants in oil and gas lease treated as dependent); Watford Oil \& Gas Co. v. Shipman, 233 Ill. 9, 84 N.E. 53 (Igo8) (oil and gas lease); Cincinnatti Exhibition Co. v. Johnson, I9o Ill. App. 630 (1914) (injunction against breach of negative covenant in baseball player's contract denied because of surrender clause); 
tiff's obligations would be barred by the doctrine that "equity will not do a vain and useless thing." But the courts' dislike for one-sided bargains is possibly the real explanation here.

A large and growing body of exceptions casts additional doubt upon the doctrine of mutuality. The enforcement of option ${ }^{57}$ and unilateral contracts ${ }^{58}$ is logically consistent with the requirement that the remedy be mutual at the time the contract is made. But even in the case of bilateral contracts involving personal services, the doctrine does not apply when the provisions which could not have been specifically enforced have been fully performed. ${ }^{59}$ Other exceptions have raised more difficulty. Specific performance has been granted the purchaser under a land contract signed only by the vendor, on the ground that the act of filing the bill has bound the plaintiff and rendered the contract mutual. ${ }^{60}$ Yet this relief was recently denied the purchaser of land who had acted as undisclosed principal in the transaction. ${ }^{61}$ Again, in Lunt v. Lorscheider, ${ }^{62}$ involving a contract for the exchange of lands, the doctrine of mutuality was thought to prevent specific performance in favor of an assignee for value who had assumed none of the obligations of the original contract even though all of the parties were before the court. But in a later case, Leveis v. $\mathrm{McCreedy},{ }^{63}$ where the contract was for the sale of land, a contrary result was reached without any mention of the Lunt case. Perhaps the most unhappy experience was Gage v. Cummings. ${ }^{64}$ There the plaintiff had agreed to exchange land owned in part by his wife. She executed deeds of conveyance to the defendant and was a party plaintiff in the bill, but because she had not been a party to the contract the court refused specific performance. The case was quickly qualified, ${ }^{65}$ has never been followed, and perhaps may be regarded as overruled.

cf. Peru Wheel Co. v. Union Coal Co., 295 Ill. App. 276 (1938) (covenant in lease of right of way, whereby defendent lessee promised to furnish at a fixed price the coal screenings needed in lessor's business denied enforcement because the lessor was under no obligation to purchase coal from the defendant).

${ }^{57}$ Arentsen v. Sherman Towel Service Corp., $35^{2}$ III. 327 , 185 N.E. 822 (1933) (option to buy); Anderson v. Bills, 335 Ill. 524, I67 N.E. 864 (1929) (option to sell).

${ }^{58}$ See Anderson v. Bills, 335 Ill. $524,528,167$ N.E. 864,866 (I929). But cf. Bauer v. Lumaghi Coal Co., 209 Ill. 3 I6, 70 N.E. 634 (I904).

${ }^{59}$ Oswald v. Nehls, 233 Ill. 438,84 N.E. 6 rg (I908); cf. Elmore Real Estate Imp. Co. v. Olson, 332 Ill. App. 475, 76 N.E. 2d 204 (1947).

${ }^{60}$ Ullsperger v. Meyer, 217 Ill. 262, 75 N.E. 482 (x905).

${ }^{61}$ Wloczewski v. Kozlowski, 395 Ill. 402,70 N.E. 2 d 560 (I946) (lack of mutuality was only one of three alternative grounds of decision).

62 285 Ill. 589 , x2I N.E. 237 (xgI8).

${ }^{63} 378$ Ill. 264,38 N.E. 2 d 170 (194I).

64209 IIl. 120,70 N.E. 679 (1904).

${ }^{65}$ In Gibson v. Brown, $2{ }_{4}$ Ill. 330, 337, 73 N.E. 578, 580 ( $\mathrm{rg}_{95}$ ), the doctrine of the Gage case was held inapplicable because the plaintiff had perfected title in himself and tendered a good conveyance before filing his bill. A further "exception" has been made when a spouse who 
Judicial resistance to Fry's doctrine has been more than matched by the criticism of the writers. ${ }^{66}$ The Restatement of Contracts has substituted the rule that "[s]pecific performance may properly be refused if a substantial pait of the agreed exchange for the performance to be compelled is as yet unperformed and its concurrent or future performance is not well secured to the satisfaction of the court." ${ }^{137}$ The emphasis has switched from purely formal notions of equality to actual injustice and oppression which might result from a decree. ${ }^{68}$ Whether the Illinois courts are ready to go this far remains conjectural. There has been some recognition of the conditional decree as a means of insuring the plaintiff's performance. ${ }^{69}$ Moreover, the courts have occasionally said that "[s]pecific performance . . . will not be denied where there is a fair and valid contract and the party seeking performance has performed or offered to perform all of the terms and conditions required of him."70 But possibly these dicta are not directed at the doctrine of mutuality. ${ }^{71}$ Certainly the lack of express judicial criticism of the old rule must be weighed against them. ${ }^{72}$

IV

Limitations upon the availability of specific performance may be avoided to some extent by the enforcement of negative provisions in contracts. Though the injunction against breach of contract is generally treated like a decree for specific performance, ${ }^{73}$ it is sometimes said that "where there is an express negative covenant, courts of equity will entertain bills for injunctions to prevent their violation, even though the same will occasion no substantial injury,

has not signed the contract has joined in a deed releasing his or her dower interest. Cohen $\mathrm{v}$. Segal, 253 Ill. 34, 45, 97 N.E. 222, 225 (IgIr).

${ }^{60}$ See Cook, The Present Status of the "Lack of Mutuality" Rule, 36 Yale L.J. 897 (r927); Stone, The "Mutuality" Rule in New York, I6 Col. L. Rev. 443 (I916); Lewis, The Present Status of the Defense of Want of Mutuality in Specific Performance, 5I Am. L. Reg. $59 \mathrm{I}$ (1903); Ames, Mutuality in Specific Performance, 3 Col. L. Rev. I (1903).

67 Rest., Contracts $\$ 373$ (1932).

${ }^{68}$ This is the approach in Epstein v. Gluckin, 233 N.Y. 490, 135 N.E. 86 I (1922), and Zelleken v. Lynch, 80 Kan. 746, 104 Pac. 563 (19\%9).

${ }^{60}$ See Kuehnle v. Augustin, 333 Ill. 3I, 35, I64 N.E. I94, I96 (I928); Rowell v. Covenant Mutual Life Ass'n, 84 Ill. App. 304, 315 (1899).

${ }^{70}$ Edmonds v. Gourley, 362 Ill. I47, 156, r99 N.E. 287, 29I (1935); Greengard v. Bernstein, 343 Ill. 4I6, 4I9, I75 N.E. 424, 425 (I93I).

"I In Greengard v. Bernstein, 343 IIl. 416, I 75 N.E. 424 (I93I), no question of lack of mutuality was raised, the problem being one of sufficiency of tender. However, the court in Edmonds v. Gourley, 362 Ill. r47, I99 N.E. 287 (r935), certainly appeared to refer to the doctrine of mutuality.

72 But see Ellis Electrical Corp. v. Ellis, 269 Ill. App. 417, 426 (1933).

${ }^{78}$ See East St. Louis Ry. Co. v. East St. Louis, I82 Ill. 433, 437, 55 N.E. 533, 535 (1899); Chicago Municipal Gas-Light \& Fuel Co. v. Town of Lake, 130 Ill. 42, 60, 22 N.E. 616, 619 (1889); Lee v. Chicago League Ball Club, I69 Ill. App. 525, 530 (19I2). 
or though the remedy be adequate at law." 74 This has been the rule regarding the use of leased premises for unauthorized purposes..$^{75}$ And injunctions have been issued as a matter of course where the seller of a business has agreed not to compete ${ }^{76}$ or an employee has promised not to disclose trade secrets or steal customers. ${ }^{77}$ However, the doctrine has no general application. The cases, like those involving the specific performance of land contracts, present special situations where the courts will assume damages inadequate without inquiry into the particular facts. ${ }^{78}$ The negative covenant does not offer escape from the requirement that the legal remedy be inadequate, in the case of an ordinary contract for the sale of personalty.

Negative promises contained in a contract for extended performance can often be enforced without inconvenience, and the resulting economic pressure may compel the defendant to perform his affirmative obligations as well. Such a "negative specific performance" was decreed in the leading English case of Lumley v. Wagner. ${ }^{79}$ Though the court was unwilling to command Miss Wagner to sing at Mr. Lumley's theatre, an injunction was issued to prevent violation of her agreement not to perform elsewhere. The Illinois courts have never enforced an employment contract in this way. They have held that the services of a millinery trimmer ${ }^{80}$ or factory foreman ${ }^{81}$ were not sufficiently "intellectual, peculiar, or individual in their character." The requirement of an inadequate legal remedy appears to be reinforced by the courts' notions of personal liberty. ${ }^{82}$ The doctrine of Lumley $v$. Wagner has been applied more often in cases involving exclusive selling agreements where the courts have enjoined the

${ }^{4}$ Andrews v. Kingsbury, 212 Ill. 97, ז02, 72 N.E. Ix, $\Upsilon_{3}$ (I904).

${ }^{75}$ Consolidated Coal Co. v. Schmissuer, I35 Ill. 37I, 25 N.E. 795 (I89o).

${ }^{76}$ Andrews v. Kingsbury, 2r2 Ill. 97, 72 N.E. Ix (1904); Hursen v. Gavin, x62 Ill. 377, 44 N.E. 735 (I896); Cobbs v. Niblo, 6 Ill. App. 60 (r880). If, however, the contract imposes an unreasonable restraint on trade it will not be enforced. Lanzit v. J. W. Sefton Mfg. Co., I84 Ill. $326,5^{6}$ N.E. 393 (I900).

${ }^{77}$ International Mutual Fire Ins. Co. v. Carrington, 24I Ill. App. 208 (I926); Hoops Tea Co. v. Dorsey, 99 Ill. App. I8I (rgoI); Cahill v. Madison, 94 Ill. App. 2 I6 (IgOI). But when the courts have found the contract unfair or harsh they have refused to issue an injunction. India Tea Co. v. Petersen, Io8 Ill. App. I6 (Ig03); Oppenheimer v. Sayer, I Ill. C.C. 74 (I89o).

${ }^{78}{ }_{5}$ Williston, Contracts $\S$ I445 (rev. ed. 1937).

79 I De Gey, MacNaghten \& Gordon 604 (1852).

${ }^{80}$ Rabinovich v. Reith, I20 Ill. App. 409 (I905).

81 Donker \& Williams Co. v. Vance, 2 Ill. C.C. I2 $(x g \infty)$ ).

82 The argument is similar to that made in the building contract cases-unless the defendant's services are unique, he can be replaced by some third party whose pay will provide a convenient measure of damages. Concern for the employee's personal liberty is most clearly evidenced in Donker \& Williams Co. v. Vance, 2 Ill. C.C. I2 (rgoo), where the court argued that an injunction should never issue when the contract called for close personal association between employer and employee. But cf. Cahill v. Madison, 94 Ill. App. 2 I6 (Igor). 
breach of covenants not to sell to third parties. ${ }^{83}$ In these cases the plaintiff has been threatened with "irreparable injury" through competition, quite apart from any breach of the defendant's affirmative obligation to supply goods. However, with regard to ordinary output or requirement contracts, an absence of adequate legal remedy for the defendant's failure to sell or buy might possibly furnish sufficient basis for this sort of relief. ${ }^{84}$ Whether or not an express negative promise by the defendant is necessary in order to obtain an injunction is in all of these cases an open question. ${ }^{85}$

In Welty $v$. Jacobs, ${ }^{86}$ the court indicated that lack of mutuality was a defense against the enforcement of the negative covenants in a contract. Because there could be no specific performance of the plaintiff's agreement to "play his company in the 'Black Crook' " at the defendant's theatre, the court refused to enjoin interference with the plaintiff's performance, the presentation of the play by a rival company, and failure to furnish lighting and the like. The later case of $B$. \& R. Brewing Co. v. Modzelewski, 87 involving a requirement contract, appears at first blush to follow this rule. But the court did in fact only require a showing of inadequacy of legal remedy as a consequence of the want of mutuality. In the enforcement of negative covenants even the eminently sensible requirements of Section 373 of the Restatement of Contracts appear to have been disregarded. ${ }^{88}$ An arbitrary exception has been engrafted upon the arbitrary rule.

\section{V}

The Illinois cases do not reveal any strong and sure trend towards modernization of the rules governing specific performance. Legislation appears neces-

${ }^{83}$ Southern Fire Brick and Clay Co. v. Garden City Sand Co., 223 Tll. 6r6, 79 N.E. $3^{\text {I } 3}$ (1906); Match Corp. of America v. Acme Match Corp., 285 Il. App. 197, I N.E. 2d 867 (1936); Ellis Electrical Corp. v. Ellis, 269 Ill. App. 4I7 (I933); American Sand \& Gravel Co. v. Chicago Gravel Co., 284 Ill. App. $5 \circ 9$ (IgI4).

${ }^{84}$ See B. \& R. Brewing Co. v. Modzelewski, 269 Ill. 539, 547-49, I09 N.E. I058, 106x-62 (rgI5), refusing to enforce "negatively" a requirement contract because the agreement contained a provision for liquidated damages. But it has been argued that this remedy is inconsistent with the theory of relief inasmuch as performance is not assured. See Bour v. Ml. Central R. Co., I76 Ml. App. I85, 202 (I9I2) (contract for exclusive advertising rights in railroad cars); Grape Creek Coal Co. v. Spellman, 39 Ill. App. 630, 632 (I8gr) (output contract).

${ }^{85} \mathrm{It}$ is perhaps mere chance that all of the exclusive selling agreements enforced in this manner have contained express negative covenants. Cases cited note 83 supra. However, in Rabinovich v. Reith, I20 Ill. App. 409 (rgo5), the court suggested that an express covenant would be necessary in the case of an employment contract.

${ }^{80}$ I7x Ill. 624, 49 N.E. 723 (I898).

${ }^{87} 269$ Ill. 539, rog N.E. ro58 (x915).

${ }^{88}$ Cases cited note 83 supra; cf. International Mutual Fire Ins. Co. v. Carrington, $24 \mathrm{x} \mathrm{Il}$. App. 208 (rg26). Contra: Cincinnati Exhibition Co. v. Johnson, Igo Mll. App. 630 (rgr4). Though the courts have made flat statements that the doctrine of mutuality has no application in these cases, it does not appear that they have yet been faced with a situation where there is a strong likelihood of breach by the plaintiff. 
sary if the law is to correspond with practical needs rather than with historical dogma. There has already been some legislative action in this field. In the event of breach or threatened breach of the agreement of a member of a cooperative marketing association to sell his crops through the association, the Agricultural Co-operative Act provides that "the association shall be entitled to an injunction to prevent the further breach of the contract and to a decree of specific performance thereof." 89 However, injunctions would probably be available even in the absence of any statute. Though these contracts normally provide for liquidated damages as well as injunctive relief, courts have strongly sympathized with the aim of the associations to stabilize agricultural markets and prevent "speculation or waste in the production, distribution and marketing of products." "80

According to Section 68 of the Uniform Sales Act, "[w]here the seller has broken a contract to deliver specific or ascertained goods, a court having the powers of a court of equity may, if it thinks fit, on the application of the buyer, by its judgment or decree direct that the contract shall be performed specifically. ... ."91 Professor Williston, the draftsman of the act, stated that "this section ... will perhaps dispose courts to enlarge somewhat the number of cases where specific performance is allowed." ${ }^{\text {"92 }}$ But in Illinois the provision has been virtually ignored, except in the case of G. C. Outten Grain Co. v. Grace. ${ }^{93}$ And there the appellate court said that the section merely codified the common law. Adoption of the "liberal rule" of the Ohio and Michigan courts" thus seems unlikely..$^{95}$

A more effective statute would require the court to grant the remedy requested by the plaintiff except in cases where another form of relief was better calculated to secure the equivalent of performance. Because either specific performance or the declaratory judgment would provide a more adequate remedy, it would seem proper to refuse anticipatory damages in cases like that of disa-

${ }^{89}$ IIl. Rev. Stat. (I947) c. $32, \S 45^{8}(\mathrm{~b})$.

${ }^{90}$ See Farmer's Ed. \& Co-op. Union v. Langlois, 258 Ill. App. 522 (I930); Milk Producers Marketing Co. v. Bell, 234 Ill. App. 222 (I924) (association not incorporated under the Agricultural Co-operative Act).

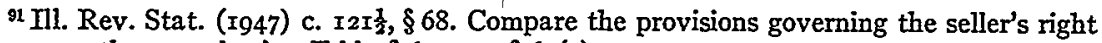
to recover the agreed price. Ibid., $\S 6_{3}$, esp. $\S 6_{3}(3)$.

${ }^{92} 3$ Williston, Sales $\S 60$ I (rev. ed. I948). As to the seller's right to the price, see ibid., $\$ \S 56$ et seq.

${ }^{93} 239$ Ill. App. 284 (I925).

94 The leading cases are Michigan Sugar Co. v. Falkenhagen, 243 Mich. 698, 220 N.W. 760 (Ig28), and Hughbanks v. Browning, 9 Ohio App. II4 (IgI7).

${ }^{95}$ Section 118 of the Uniform Revised Sales Act offers even less hope for liberalization of the rules governing specific performance. It reads as follows: "Specific performance may be decreed where the goods are unique or in other proper circumstances." 
bility insurance. ${ }^{96}$ Possibly such a rule should also be applied to installment contracts where the court in awarding damages must guess about future market conditions. ${ }^{97}$ But perhaps whenever the breach is particularly blameworthy, the plaintiff should be allowed his option of remedies. Additional rules limiting the specific enforcement of personal service contracts and redefining the doctrine of mutuality would be desirable. Finally, the statute should expressly provide against the extension of land contract doctrines of equitable property as a consequence of increased availability of specific performance. ${ }^{98}$ There is no practical need in the informal sales law for such a development and the resulting confusion about titles might defeat the greater goal of security of expectation.

${ }^{2}$ New York Life Ins. Co. v. Viglas, 297 U.S. 672 (1936); cf. Fleming v. Peterson, I67 Ill. 465, 47 N.E. 755 (1897); see 5 Williston, Contracts $§$ I330 A (rev. ed. 1937). (rgo3).

${ }^{97}$ Compare St. Regis Paper Co. v. Santa Clara Lumber Co., I73 N.Y. r49, 65 N.E. 967

${ }^{98}$ Compare Bowman v. Adams, 45 Idaho 217, 26I Pac. 679 (1927). 